Краматорськ: Центр продуктивності, 2005. - Вип. 1: Професії працівників, які $€$ загальними для всіх видів економічної діяльності. - 363 с. 2. Должностные обязанности специалистов колхоза в условиях полного хозрасчета / Сост. Г. А. Баклаженко. - М. : Росагропромиздат, 1989. - 416 с. 3. Лузан П. Г. Теорія професійної підготовки спеціалістів : [текст]/ П. Г. Лузан, П. М. Решетнік, Н. С. Журавська. - К. : Видавничий центр НАУ, 2003. - 130 с. 4. Манько В. М. Теоретичні та методичні основи ступеневого навчання фахівців 3 механізації сільського господарства : [текст] / В. М. Манько, В. В. Іщенко. - К. : Аграрна освіта, 2003. - 431 с. 5. Олійник Ю. С. Методика тестування знань 3 електромагнітних перехідних процесів у майбутніх інженерів-електроенергетиків : автореф. дис. на здобуття наук. ступеня канд. пед. наук : спец. 13.00.02 «Теорія і методика навчання» / Ю. С. Олійник. $-\quad$ Х., 2011. - 20 c. $\quad$ 6. Солошин I. О. Методика формування екологічних знань у майбутніх інженерів-електромеханіків у процесі навчання спеціальних дисциплін : автореф. дис. на здобуття наук. ступеня канд. пед. наук : спец. 13.00.02 «Теорія і методика професійної освіти»/ I. О. Солошин. - Харків, 2006. $-20 \mathrm{c}$.

\title{
ПРОБЛЕМИ ФАХОВОЇ ПІДГОТОВКИ СТУДЕНТІВ-ГЕОДЕЗИСТІВ
}

Куліковська О. С. Проблеми фахової підготовки студентів-геодезистів.

У статті проаналізовано результати анкетування студентів-геодезистів 1-5 курсів щодо їхнього ставлення до освітнього процесу у Криворізькому національному університеті. Розглянуто сутність і особливості застосування роздавальних анкет, визначено мету опитування, розроблено форму і запитання анкети. Відображено запитання, пов'язані з оцінкою якості навчання, судженням достатності лекційних, лабораторних і семінарських занять, оцінюванням відвідуваності й інтересу до навчання загалом, до проведення навчальних і виробничих практик.

Ключові слова: студенти-геодезисти, анкетування, освітній процес, якість навчання, інтерес до навчання, репрезентативність.

Куликовская О. Е. Проблемы профессиональной подготовки студентовгеодезистов.

В статье проанализированы результаты анкетирования студентов-геодезистов 1-5 курсов их отношения к образовательному процессу в Криворожском национальном университете. Рассмотрены сущность и особенности применения раздаточных анкет, определена цель опроса, разработаны форма и вопросы анкеты. Отражены проблемы, которые связаны с оценкой качества обучения, суждение о достаточности лекционных, лабораторных и семинарских занятий, оценка посещаемости и интереса к обучению, к проведению учебных и производственных практик.

Ключевые слова: студенты-геодезисты, анкетирование, образовательный процесс, качество обучения, интерес к учебе, репрезентативность.

Kulikovska O. Ye. Problems of professional training of students of surveyors.

The article analyzes the results of the survey of students surveyors of 1-5 years of study in relation to the educational process in Krivoy Rog national University. The article considers the nature and peculiarities of distributing questionnaires, defines the purpose of 
the survey design and the questionnaire. Addresses issues associated with the assessment of the quality of education, the judgment of the adequacy of lecture, laboratory and seminar classes, evaluation of attendance and interest in learning in General to conducting training and operational practices are highlighted.

Key words: the students-surveyors, surveys, educational process, the quality of learning, interest in learning, representation.

Метою пропонованої статmі є забезпечення кафедри геодезії Криворізького національного університету одержанням систематичної інформації щодо перебігу ставлення студентів-геодезистів до освітньої діяльності.

Об'єктом дослідження є студенти денної форми навчання напряму підготовки «Геодезія, картографія та землеустрій» спеціальності «Геодезія».

На першому етапі досліджено ставлення студентів-геодезистів до організації та якості навчального процесу. Контроль вибірки здійснювався на основі статистичних даних за курсами. Усього на 1-5 курсах денної форми навчається 151 особа, обсяг вибірки - 112 осіб, що становить приблизно 74,7 \% від загальної сукупності. Аналіз розподілу за курсами показав: він достатньо пропорційний, щоб уважати вибірку репрезентативною, а дані - достовірними.

В анкеті запропоновано питання, пов'язанні 3 оцінюванням якості навчання, кількістю лекційних, лабораторних і семінарських занять, оцінюванням відвідування та інтересу студентів до навчання.

Одне із питань анкети пов'язане зі встановленням причини вступу за напрямом навчання «Геодезія, картографія та землеустрій», а також на спеціальність «Геодезія». Опрацювання результатів дозволило встановити те, що серед першорядних причин вступу студенти обрали запропоновану відповідь: «С спеціальність, яка мене цікавить». Така відповідь була характерною для студентів усіх п’яти курсів, тобто переважало професійне спрямування навчання.

Окрім зазначеного, можна також наголосити, що «зручне розташування ВНЗ» та поради родичів і знайомих також достатньо вагомо впливали на вибір фаху навчання (рис. 1). 3 часом ставлення до майбутньої професії у 38,5 \% студентів змінюється на краще; не задоволеними обраною професію стають 9,9\%, а 51,6\% студентів не змінили свого ставлення до обраного фаху (рис. 2).

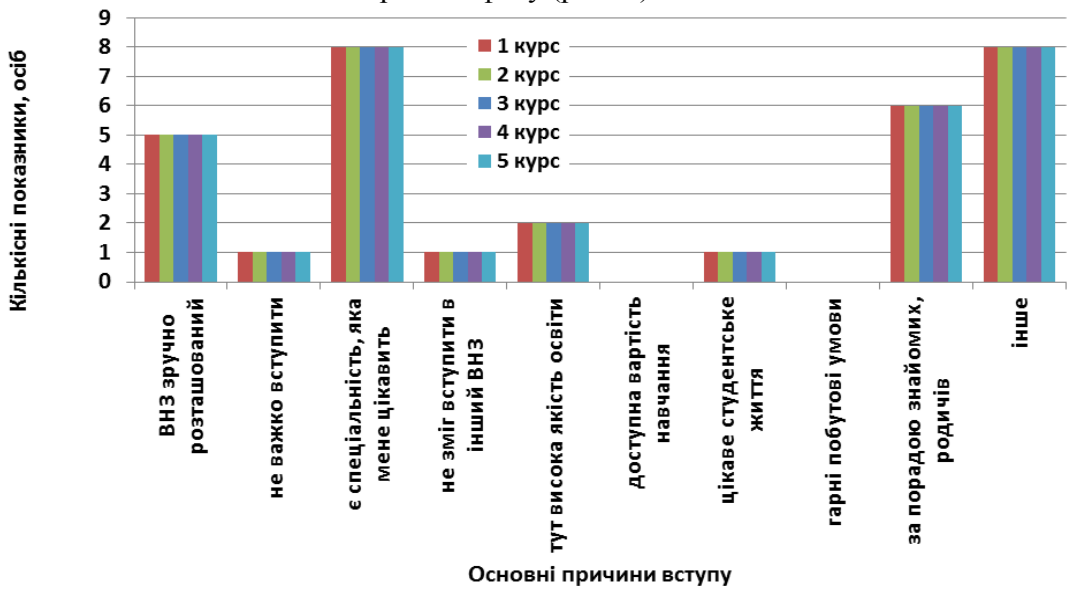

Рис. 1. Результати анкетування щодо причин вступу на спеціальність

Педагогіка вищої та середної школи. - 2015. - Вип. 44 


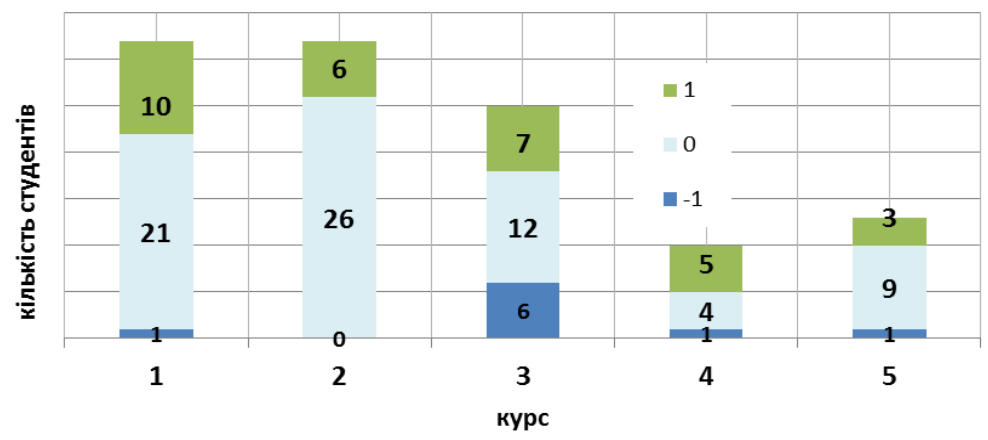

Рис 2. Результати опитування щодо зміни ставлення до обраної спеціальності за час навчання

Студентам, які брали участь в опитуванні, було запропоновано оцінити якість навчання на своєму курсі за п'ятибальною шкалою від «-2» до «+2». Результати такого оцінювання подано на рис. 3.

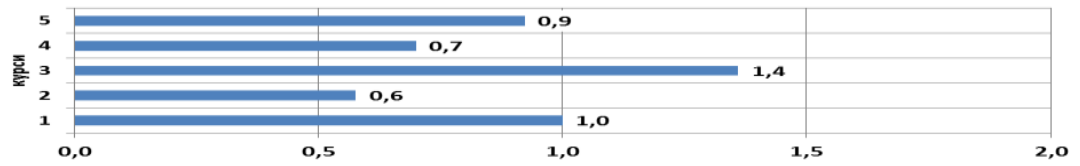

Рис. 3. Оцінка якості навчання залежно від курсу

За опитуванням мінімальну оцінку за якість навчання, яка дорівнює $+0,6$ балів отримано для 2 курсу, а максимальну - для 3 курсу (+1,4 балів). При цьому середнє значення показника складає $+0,9$ балів із максимальних $+2,0$ балів.

Цікавими видалися відповіді студентів на запитання щодо того, чи вдалося викладачам показати зв'язок дисциплін професійного циклу з майбутньою роботою. Результати опитування можна наочно відобразити гістограмою, поданою на рис 4. Показати зв'язок дисциплін професійного циклу 3 майбутньою роботою вдалося тільки окремим викладачам $(50,0 \%)$, а $7,3 \%$ викладачів практично не продемонстрували цей зв'язок.

На запитання: «Чи відчули зацікавленість викладачів у тому, щоб Ви стали фахівцем високого рівня?», опитувані студенти відповіли «так» у 45,2 \% випадків; $47,6 \%$ відповіли - «ні» і тільки 7,3\% респондентів не відчули зацікавленості викладачів у становленні студентів фахівцями високого рівня.

На особливу увагу заслуговує питання щодо організації навчальних i виробничих практик. На запитання, «Чи задовольняє Вас якість організації та проведення практик?», 85,0 \% студентів відповіли - «так»; 13,8 \% - «ні» (проведені практики не дали мені уявлення про специфіку моєї спеціальності); інше - 1,3\%. Аналіз отриманих кількісних показників надає підстави засвідчити, що переважну більшість студентів все ж таки задовольняє організація та проведення практик. 


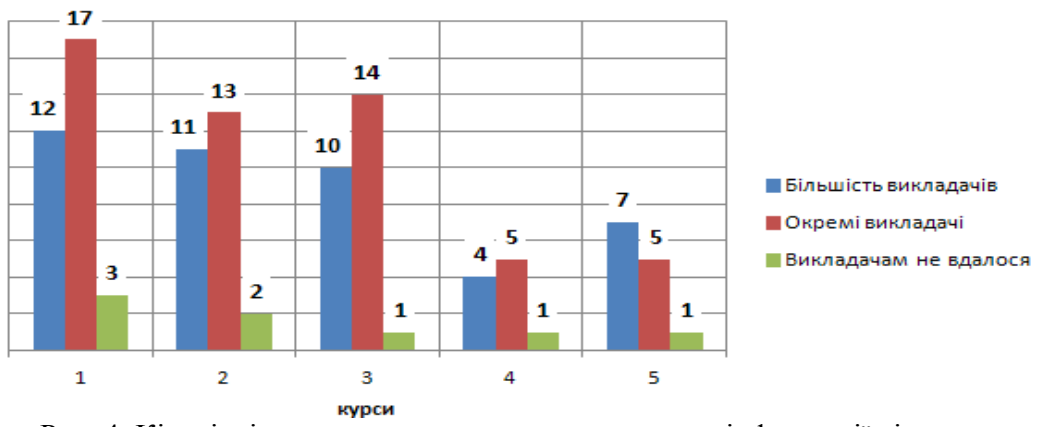

Рис. 4. Кількісні показники одержання студентами інформації від викладачів щодо зв’язку навчальних дисциплін із майбутньою професією

Оцінка достатності лекційних і семінарських занять засвідчила, що студенти аудиторне навантаження уважають оптимальним. Збільшити кількість лекцій (50 \% студентів) і зменшити кількість лабораторних занять та семінарів (35\% студентів) активніше за інших просять студенти 1 курсу.

Аналіз про відвідування студентами занять показав, що основними причинами пропуску є хвороба, погане самопочуття або непередбачувані обставини. Загалом відвідування занять - задовільне, пропуски - у 77,5 \% випадків із поважних причин.

Опитуваним студентам було також запропоновано оцінити інтерес до навчання (спеціальність «Геодезія») за семибальною шкалою від -3 до +3 . Середній бал, отриманий у ході опитування, становить $+1,4$ (швидше цікаво). Помітною $є$ оцінка інтересу до навчання залежно від курсу, на якому навчається студент: спостерігається приблизно однаковий рівень зацікавленості студентів освітнім процесом (рис. 5).

Студенти всіх курсів позитивно оцінюють свій інтерес до навчання, але абсолютні показники не великі (знаходяться в межах від $+1,3$ до $+1,5$ за максимального значення $+3,0)$.

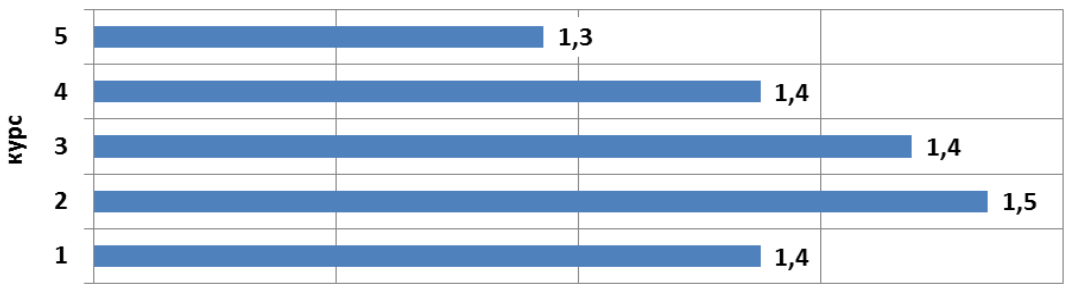

Рис. 5. Рівні зацікавленості студентів до освітнього процесу в залежності від курсу навчання

Отже, проведене дослідження дозволило виявити та систематизувати аспекти ставлення студентів до навчально-пізнавальної діяльності, обраної спеціальності, що дозволяє внести корективи в планування ефективної освітньої діяльності у підготовці фахівців-геодезистів задля формування позитивного ставлення студентів до навчально-пізнавальної діяльності. 